\title{
PSYCHOLOGICAL AND PEDAGOGICAL FEATURES OF STUDENTS' ADAPTATION TO STUDYING AT HIGHER EDUCATION INSTITUTIONS
}

\author{
LIUBOMYRA ILIICHUK, OLEKSII VOROBETS
}

\begin{abstract}
The article describes the peculiarities of the process of students' adaptation to studying at a higher education institution, emphasizes the relevance of this problem in the context of the issue of training highly qualified specialists capable of effective work in the specialty at the level of world standards, ready for continuous professional improvement and personal development. The paper emphasized that the period of adaptation is a particularly important stage of studying at a higher education institution. It is particularly relevant when higher education students adapt to the content and nature of the educational process, in the period of adoption of norms and requirements of the new social environment, inclusion in the system of interpersonal relations, formation of a system of personal orientations, values, necessary for professional activity. The relationship between students' academic success and their level of adaptation to studying at a higher education institution has been identified. The results of an experimental study are presented, where the main factors of adaptation of higher education students, affecting their activity and academic success, are identified. Among these factors, the authors singled out magnitude of educational and extracurricular workload, working capacity during the school day and week, health condition, manifestation of various signs of fatigue, self-efficacy, motivation to learning, relationships with classmates and teachers, social frustration. The researchers stressed that the first-year students' adaptation period is different, depending on their individual and psychological characteristics, the level of readiness to study at a higher education institution, the correct choice of the future profession. On the basis of the results of the experimental study, the ways and directions of successful students' adaptation are determined, which foresees, first of all, the reduction of the impact of maladaptation factors on higher education students, increase in their resistance to these factors and strengthening of those factors that are favorable to them.
\end{abstract}

Keywords: adaptation, adaptation process, forms of adaptation, factors of adaptation, educational activity, academic success, institution of higher education, first-year student, future primary school teachers.

\section{INTRODUCTION}

Studying at a higher education institution is one of the most important periods in the life of a modern young person when personal growth and professional becoming takes place. These processes are efficient, some students quickly adapt to changed social conditions and new activity, which cause the replacement of the dynamic stereotype and emotional experiences associated with it. The entry of 
yesterday's pupil into the system of higher education is characterized by a great dynamic of mental processes, which is caused by the novelty of the student status, the lack of a reference group, the intense mode of study, which becomes more complex in form and content. A special role in this process belongs to the educational activity, which is associated with receiving, processing and communicating a large amount of information and is characterized by regular fatigue, high emotional load, stressful situations that occur from time to time. Stress factors affecting students also include misunderstanding or insufficient knowledge of subjects, high intensity of studying, conflicts with peers and teachers, malnutrition, lack of time, lack of physical activity, etc.

The adaptation period, which lasts for the first months of studying in a higher school, is an important stage in students' lives. It is during this period that the assimilation of a new way of life, qualitatively other forms of relations with teachers and administration, a new social environment, adaptation to changed living conditions take place. Therefore, the functional systems of the freshman's body are not operating at an optimum level at this time, their energy reserves, the level of emotionalvolitional and cognitive processes, physiological indicators of the state of the organism, the renewable capabilities of the body and overall performance are significantly reduced. Thus, according to various experimental studies, more than half of the first-year students suffer from sleep disorders. About $80 \%$ undergo excessively strong emotional experiences; one third of students have low levels of mood, suffer from psychosomatic disorders, which is manifested in nervous system arousal and loss of emotional control; a quarter of students have chronic somatic diseases; about $70 \%$ of students experience fatigue at the end of the work day, 35\% suffer from decreased attention [5].

Taking into account the tendency for deterioration of the health condition of the students, whose educational activity is characterized by intense mental and emotional load, regular fatigue, stressful situations, which often leads to various forms of impairment of their mental and physical health, it is obvious that there is a need to identify and overcome maladaptation factors that prevent effective freshmen's learning activity. In the experimental study, the results of which are outlined below, we have identified and characterized the importance of various adaptation factors, taking into account the peculiarities of students' educational activity. At the same time, academic success was considered an important criterion for the effectiveness of education and adaptation of higher education students to it.

\section{ANALYSIS AND Discussion}

Integration of students into the educational environment of a higher education institution is inextricably linked with the awareness and acceptance of their new social status, their inclusion in new social connections and relationships with well-defined goals, objectives, requirements and responsibilities. Therefore, students have an urgent need to adapt to living conditions and activities in accordance with new social functions and characteristics of the organization of study at a higher education institution. This process is complicated by the fact that in the process of adaptation freshmen need to overcome a number of subjective difficulties, which are caused by individual characteristics of anatomical, physiological, mental and social development, and objective difficulties, determined by the environment, circumstances, features of the educational institution activity. Thus, S. Izbash (2007) claims that in the transition from one degree of education to another, there are inevitably difficulties associated with self-expression of personal qualities in new conditions and mastering new activities. The researcher correlates the normalization of such inconsistencies with the socio-professional adaptation of students, understanding it from the standpoint of activity-personal approach as a process of personal changes in the motivational, operational and reflexive spheres of the student's personality under the influence of external and internal factors, socio-economic conditions, connected with involving the individual in the process of preparation for professional activity [3].

While researching students' adaptation to studying at a higher education institution, we proceeded from the fact that the adaptation period, which starts from the first days of studying, is a very important stage in the personal and professional development of future professionals. It involves the entry of higher education students into a new social environment, the assimilation and reproduction of 
social norms and values characteristic of this environment, mastering the respective roles and functions, developing a new model of behavior and activity [1]. Therefore, psychological and pedagogical support are important factors for successful adaptation of freshmen. Researcher G. Vasianovych (2008) identifies the following types of pedagogical support for students in the process of adaptation to studying at a higher education institution: individual, group and social. Individual support is carried out mainly in the sphere of personal adaptation by gaining experience of emotional and value relationships, which involves the identification of difficulties and problems, involving the student in self-knowledge in accordance with the self-concept, resolving intra-personal contradictions in predicting the individual trajectory of personal development. Group support involves diagnostics and coordination of influences on the group, formation of favorable psychological climate and interpersonal communication, activity of groups and collectives with participation in socially important activities, correction of intragroup relations, and involvement of personality in the activity of these groups and collectives, assisting in life conflict resolution. Social support is carried out in the social environment and aims at the student's successful adaptation to the conditions of modern society $[11$, p. 25].

In the fundamental works of leading scientists, the optimization of the adaptation process of students of higher education institutions is considered as the most important reserve for improving the effectiveness of studying. At the same time, more and more attention is given to the pedagogical provision of the freshmen's adaptation process, the general content of which includes, according to I. Sokolova (2001), three components: socio-psychological, which reflects the change of the student's social role, adjustment of his needs and value system, necessity of more flexible regulation of his behavior, acceptance of norms and traditions established in the institution of higher education; psychological, that is restructuring the student's thinking and language, sharp increase in attention and memory functions, increase in emotional tension; activity, that is students' adaptation to new psychological and physiological loads, involvement in hard educational work, overcoming a kind of "information explosion" [9, p. 28]. Researchers G. Levkivska, V. Sorochynska, and V. Shtyfurak (2001) identify the main components of the process of adaptation of freshmen to study: formal, socialpsychological and didactic [6]. V. Liesovyi (2017), who identifies physiological, social-psychological, didactic and professional components of the students' adaptation process [7], supplements this classification as well.

61 first-year students of the specialty "Primary education" of the Pedagogical faculty of Vasyl Stefanyk Precarpathian National University participated in the experimental study. In the course of the research, we used questionnaires, the methods of diagnostics of the level of social frustration of Wasserman-Boiko [5], self-efficacy scale of R. Shvarcer and M. Jerusalem [5]. Using the methods and questionnaires, information was obtained on such adaptive factors for first-year students as:

- magnitude of study load and extracurricular load;

- performance during the school day and week;

- health condition;

- manifestation of different signs of fatigue during studying;

- educational self-efficacy;

- motivation to study;

- relations with groupmates and teachers;

- social frustration.

Investigating the impact of study load and extracurricular load on the process of successful adaptation of freshmen, we proceeded from the assumption that the amount of study load is determined primarily by the average time spent by the student to prepare for the classes. With regard to extracurricular loads, this is the time used by higher education students to solve family and domestic affairs, part-time jobs, hobbies, etc. (Table 1). 


\begin{tabular}{|c|c|c|c|}
\hline The indicator & $\mathbf{1 - 2}$ hours & $\mathbf{2 , 5 - 4}$ hours & $\begin{array}{c}\text { more than } \mathbf{5} \\
\text { hours }\end{array}$ \\
\hline Study load & $41 \%$ & $52 \%$ & $7 \%$ \\
\hline Extracurricular load & $49 \%$ & $46 \%$ & $5 \%$ \\
\hline
\end{tabular}

Tab. 1. Students' assessment of study load and extracurricular load

Therefore, we can state that $52 \%$ of freshmen spend 2.5 - 4 hours preparing for classes, $41 \%-1-2$ hours and $7 \%$ - 5 hours or more. As for extracurricular load, it takes students less time, but in $5 \%$ of students, this indicator is very high.

An important stage of the study was to determine the self-assessment by higher education students of the magnitude of their study load and overall workload, which includes the time students spend preparing for academic classes and extracurricular activities during the day (Table 2).

\begin{tabular}{|c|c|c|c|c|}
\hline Load rating & Low & Normal & High & Very high \\
\hline Study load & $3 \%$ & $66 \%$ & $26 \%$ & $5 \%$ \\
\hline Overall workload & $3 \%$ & $74 \%$ & $20 \%$ & $3 \%$ \\
\hline
\end{tabular}

Tab. 2. Students' assessment of the magnitude of study load and overall workload

The received data show that more than half of the students rate their workload as normal, $26 \%$ consider it high, a small number of the freshmen think their workload is very high, and only $3 \%$ of the respondents rate it as low. The study made it possible to determine students' assessment of their overall workload, which, according to the freshmen, is normal (74\%), high (20\%), very high (3\%) and low (3\%). Overall, it can be said that only for a small number of higher education students study load and overall workload is low or very high.

Determining the performance of students during the day and week, we proceeded from the assumption that the effectiveness of freshmen's educational activity is largely determined by the level of their working capacity (Table 3).

\begin{tabular}{|c|c|c|c|}
\hline Performance & Degrades & Does not change & Improves \\
\hline During the day & $54 \%$ & $38 \%$ & $8 \%$ \\
\hline During the week & $59 \%$ & $34 \%$ & $7 \%$ \\
\hline
\end{tabular}

Tab. 3. Students' assessment of the dynamics of their performance

The results of the study show that the performance of the students during the day (51\%) and week $(54 \%)$ is worsening. In addition, this is quite understandable, because the study was conducted in the 1 st semester, when the process of adaptation of freshmen to the organization of the educational process in higher education institution is still actively taking place. The data presented by the self-assessment indicators of higher education students' performance during the day and week showed that they were significantly lower than in the study by O. Kokun (2004) [5], which found out that only $40 \%$ of students experience fatigue at the end of the day and $32 \%$ - at the end of the week.

In the course of the study, it was important to examine the students' self-assessment of their health condition, which is extremely important in the process of carrying out the educational activity and greatly influences its effectiveness (Table 4 ).

\begin{tabular}{|c|c|c|c|}
\hline Health condition & Bad & Good & Very good \\
\hline Number of students & $13 \%$ & $72 \%$ & $15 \%$ \\
\hline
\end{tabular}

Tab. 4. Students' self-assessment of their health condition 
As we can see, many students rate their health as good (72\%) and very good (15\%). However, $13 \%$ of freshmen think that they have poor health, which should be taken into account in the organization of higher education students' educational activity.

One of the important aspects of optimizing the study process in the institution of higher education is taking into account the signs of fatigue that students experience while studying. Thus, the research made it possible to state that in the process of studying freshmen experience such signs of fatigue as deterioration of health condition $(20 \%)$, decrease in working capacity $(33 \%)$, deterioration of attention $(34 \%)$, nervous tension $(26 \%)$, increase in irritability $(21 \%)$, mood instability $(26 \%)$, indifference $(24 \%)$. Note that a certain number of students indicated several signs of fatigue caused by their study, $5 \%$ did not name a single sign, $11 \%$ indicated other signs of fatigue, including drowsiness, hunger, headache.

The academic success of higher education students is most closely linked with their educational self-efficacy [2]. It is a component of such personal quality as general self-efficacy, which determines a person's success in various spheres of activity. It is advisable to emphasize that the value of self-efficacy for students is significantly increased in difficult conditions and when they achieve complicated goals [10]. Investigating the self-efficacy of freshmen, we used the self-efficacy scale of R. Shvarcer and M. Jerusalem [5] (Table 5).

\begin{tabular}{|c|c|c|}
\hline Educational Self-efficacy & Points & Number of students \\
\hline High & $30-40$ & $61 \%$ \\
\hline Average & $20-29$ & $36 \%$ \\
\hline Low & $\geq 19$ & $3 \%$ \\
\hline
\end{tabular}

Tab. 5. Educational self-efficacy of students

The results of the study showed that $61 \%$ of students demonstrated a high level of educational selfefficacy, which testifies to their potential ability to carry out successful educational activity and effectively fulfill the academic load of higher education institution. The average level of educational self-efficacy was shown by $36 \%$ of higher education students, which indicates that they have some problems in the educational sphere. In the course of the study, we found out that among students there are those whose educational self-efficacy is at a low level, which indicates that they have a pronounced disadaptation factor.

The analysis of scientific research has shown that there is a close link between student self-efficacy and student motivation to study [4]. The motivational sphere of the individual plays an important role throughout the adaptation process. This is primarily due to the fact that the leading motives play the role of a driving force that directs the activity of the individual, occurring in the external subject and social environment, as well as having an inherent emotional and meaningful side with it [8, with. 83]. Thus, examining the level of motivation of freshmen to study, it was found out that $23 \%$ of students have very high interest in studying, $45 \%$ have a high level of interest, $27 \%$ have an average level of motivation and only $5 \%$ showed a low level of interest in studying.

An important stage in the study was to identify students' evaluations of their relationships with classmates and teachers, which significantly influence the educational activities of higher education students (Table 6).

\begin{tabular}{|c|c|c|c|c|}
\hline Relationships & Bad & Mediocre & Good & Very good \\
\hline With groupmates & $5 \%$ & $22 \%$ & $50 \%$ & $23 \%$ \\
\hline With teachers & $5 \%$ & $21 \%$ & $56 \%$ & $18 \%$ \\
\hline
\end{tabular}

Tab. 6. Students' assessment of relationships with classmates and teachers

The above data indicate that there is a good relationship between students, students and teachers. In particular, students rated their relationships with classmates as very good $-23 \%$, good $-50 \%$. As for relationships with teachers, $74 \%$ of freshmen classify them as good and very good. Although there are 
students, who consider their relations with their classmates $(22 \%)$ and teachers $(21 \%)$ to be mediocre, a small number $(5 \%)$ define them as bad, which requires special attention. However, it should be noted that the relations with the groupmates turned out to be somewhat better than with the teachers.

The Wasserman-Boiko's questionnaire was used to investigate the level of social frustration of higher education students [5]. The analysis of the results on different issues that make up the level of students' social frustration made it possible to identify the most and least frustrating (maladaptation) factors for them (Table 7).

\begin{tabular}{|c|c|c|c|c|}
\hline № & Satisfaction Level & High & Medium & Low \\
\hline 1. & Living conditions & $33 \%$ & $43 \%$ & $24 \%$ \\
\hline 2. & Financial condition & $28 \%$ & $24 \%$ & $48 \%$ \\
\hline 3. & The sphere of services and household services & $24 \%$ & $30 \%$ & $46 \%$ \\
\hline 4. & Health care sphere & $21 \%$ & $31 \%$ & $48 \%$ \\
\hline 5. & Leisure & $54 \%$ & $24 \%$ & $22 \%$ \\
\hline 6. & Holiday opportunity & $57 \%$ & $22 \%$ & $21 \%$ \\
\hline 7. & Place of study & $74 \%$ & $18 \%$ & $8 \%$ \\
\hline 8. & Learning content & $75 \%$ & $17 \%$ & $8 \%$ \\
\hline 9. & Learning conditions & $61 \%$ & $29 \%$ & $10 \%$ \\
\hline 10. & Relationships with friends, acquaintances & $80 \%$ & $17 \%$ & $3 \%$ \\
\hline 11. & Relations with groupmates & $75 \%$ & $22 \%$ & $5 \%$ \\
\hline 12. & Relations with teachers & $74 \%$ & $21 \%$ & $5 \%$ \\
\hline 13. & Relations with the administration of the higher & $72 \%$ & $21 \%$ & $7 \%$ \\
\hline 14. & education institution & $89 \%$ & $8 \%$ & $3 \%$ \\
\hline 15. & Relations with parents & $80 \%$ & $15 \%$ & $5 \%$ \\
\hline 16. & Relations with relatives & $61 \%$ & $29 \%$ & $10 \%$ \\
\hline 17. & Relations with neighbors & $74 \%$ & $18 \%$ & $8 \%$ \\
\hline 18. & Choice of study place & $75 \%$ & $17 \%$ & $8 \%$ \\
\hline
\end{tabular}

Tab. 7. Components of students' social frustration

The study revealed the least frustrating factors for first-year students, including those related to the area of relationships (with parents, relatives, friends, classmates, teachers), as well as satisfaction with their place of study and its content. The most frustrating (maladaptation) factors for students were the sphere of services and household services, living conditions, health care, social status and financial status. Note that our study results are in line with those of O. Kokun (2004) [5].

Coming out of the results of the experimental study, we will determine the main directions of optimization of the adaptation capacity of higher education students through the influence on the overall adaptive factors that are important for them. They include enhancement of educational selfefficacy; improving health; increasing motivation to study; overcoming various signs of fatigue during study; increase of working capacity; improving relationships with groupmates and teachers. This can be achieved through trainings, individual consultations, student involvement in the socio-cultural life of the institution, participation in various competitions, foreign programs, social and educational projects, a system of financial and moral incentives, in particular, awards of the rector, scholarships, certificates, providing explanatory work on the peculiarities of the organization of the educational process in the higher education institution, the need to maintain and promote health, leading a healthy lifestyle, organizing various activities, aimed at increasing the level of interaction and communication between students, increasing the role of the curator in the adaptation of students to the conditions of study at the higher education institution. 


\section{CONCLUSIONS}

Today, the value of pedagogical work is increasing in our country, and there is an increased interest in the teaching profession, which is caused by fundamental changes in political, economic and social life. Therefore, institutions of higher education are responsible for the preparation of highly qualified specialists, for providing each student with real conditions for development, for improving the cultural and professional levels, self-improvement and self-education. Particularly an important stage of studying at a higher education institution is the period of adaptation. The period when higher education students adapt to the content and nature of the educational process, adoption of norms and requirements of the new social environment, inclusion in the system of interpersonal relationships, formation of a system of personal orientations, values and qualities, necessary for professional activity. This period is a dynamic process of physiological and psychological transformations of the personality and optimization of the learning environment. It takes place as the result of organized interaction between the teacher and the student in order to develop a strategy of effective involvement in educational activity, meeting the needs and opportunities arising in the process of studying at a higher education institution. It is clear that the main focus of this activity should be to reduce the impact on freshmen of maladaptation factors, to increase their resistance to these factors, and to strengthen those that are favorable to them.

The results of the study showed that among the common important factors of the effective adaptation of the students, which have a positive impact on their activity and academic success. There is the expedient amount of educational and extracurricular workload, high performance of the freshmen during the school day and week, satisfactory health condition, manifestation of different signs of fatigue during the study, high educational self-efficacy of higher education students, high level of their motivation to study, friendly relationship with classmates and teachers. Respectively, low selfesteem, excessive self-confidence, conflicts, poor relations with classmates, high levels of anxiety and stress, dissatisfaction with studying negatively affect the educational activity and students' success. Based on the obtained results, we determined the directions of work with first-year students of the specialty "Primary education" and carried out a number of activities to successfully adapt them to studying at Vasyl Stefanyk Precarpathian National University.

\section{REFERENCES}

[1] Bokhonkova Yu.O. Socio-psychological adaptation of freshmen to the conditions of higher educational institutions: monograph. Volodymyr Dahl East Ukrainian National University, Lugansk, 2011. (in Ukrainian)

[2] Chemers M.M., Hu L., Garcia B.F. Academic self-efficacy and first-year college student performance and adjustment. Journal of Educational Psychology, 93 (1) (2001), 55-64. doi: 10.1037/0022-0663.93.1.55

[3] Izbash S.S. Project activity as a factor of social and professional adaptation of students of the pedagogical university. Central Institute of Postgraduate Teacher Education Academy of Pedagogical Sciences of Ukraine, Kyiv, 2007. (in Ukrainian)

[4] Kirk A.K., Brown D.F. Latent constructs of proximal and distal motivation predicting performance under maximum test conditions. Journal of Applied Psychology, 88 (1) (2003), 40-49. doi: 10.1037/00219010.88.1.40

[5] Kokun O.M. Optimization of human adaptive capacity: psychophysiological aspect of providing activities: a monograph. Milenium, Kiev, 2004. (in Ukrainian)

[6] Levkivska H.P., Sorochynska V.Ye., Shtyfurak V.S. Adaptation of freshmen in the conditions of higher education institution: a monograph. Lybid, Kyiv, 2001. (in Ukrainian) 
[7] Liesovyi V.Yu., Petruk V.A. Adaptation of freshmen to study in higher technical education institutions: a monograph. Vinnytsia National Technical University, Vinnytsia, 2017. (in Ukrainian)

[8] Rean A.A., Kudashev A.R., Baranov A.A. Psychology of personality adaptation. Prajm-Euroznak, St. Petersberg, 2008. (in Russian)

[9] Sokolova I.M. Student adaptation research methods. Kharkiv Medical University, Kharkiv, 2001. (in Russian)

[10] Vancouver J.B., Thompson C.M., Williams A.A. The changing signs of relationships among selfefficacy, personal goals, and performance. Journal of Applied Psychology, 86 (4) (2001), 605-620. doi: 10.1037/0021-9010.86.4.605

[11] Vasianovych H.P. Psychological and pedagogical bases of professional adaptation of future specialists: monograph. SPOLOM, Lviv, 2008. (in Ukrainian)

Address: Liubomyra Iliichuk, Oleksii Vorobets, Vasyl Stefanyk Precarpathian National University, 57, Shevchenko Str., Ivano-Frankivsk, 76018, Ukraine.

E-mail: liubomyra.iliichuk@gmail.com ; oleksiyvorobets@ukr.net

Received: 03.01.2020; revised: 10.03.2020.

Ідійчук Дюбомира, Воробець Олексій. Психолого-педагогічні особливості адаптації студентів до навчання у закладах вищої освіти. Журнал Прикарпатського університету імені Василя Стефаника, 7 (1) (2020), 184-191.

У статті розкрито особливості процесу адаптації студентів до навчання у закладі вищої освіти, підкреслено актуальність означеної проблеми в умовах, коли актуалізується питання підготовки висококваліфікованих фахівців, здатних до ефективної роботи зі спеціальності на рівні світових стандартів, готових до постійного професійного удосконалення та особистісного зростання. Підкреслюється, що період адаптації є особливо важдивим етапом навчання у вищій школі, коли відбувається пристосування здобувачів вищої освіти до змісту і характеру навчального процесу, прийняття норм та вимог нового соціального середовища, включення до системи міжособистісних стосунків, формування системи особистісних орієнтацій, цінностей і якостей, необхідних для професійної діяльності. Виявлено взаємозв'язок між навчальною успішністю студентів і рівнем їх адаптованості до навчання у закдаді вищої освіти. Представдено резудьтати експериментадьного дослідження, у процесі якого визначено основні фактори адаптації здобувачів вищої освіти, що позначаються на їх діяльності та навчальній успішності, серед яких: величина навчального й позанавчального навантаження, працездатність впродовж навчального дня і тижня, стан здоров'я, прояв різних ознак втоми під час навчання, навчальна самоефективність, мотивація до навчання, стосунки з однокурсниками та викладачами, соціальна фрустрованість. Наголошено на тому, що адаптаційний період у першокурсників проходить по-різному, залежно від їхніх індивідуальнопсихологічних особливостей, рівня готовності до навчання у вищій школі, правидьності вибору майбутньої професії. Виходячи із результатів експериментального дослідження, визначено шляхи та напрями успішної адаптації студентів, які передбачають насамперед зменшення впливу на здобувачів вищої освіти дезадаптаційних факторів, підвищення їх стійкості до цих факторів та підсилення тих факторів, які є для них сприятливими.

Кдючові слова: адаптація, адаптаційний процес, форми адаптації, фактори адаптації, навчальна діяльність, навчальна успішність, заклад вищої освіти, студент-першокурсник, майбутні учителі початкової школи. 